\title{
Frequency and characteristics of thyroid dysfunction in pregnant women - screening of 547 women in Bulgaria
}

\author{
Anna-Maria Borissova ${ }^{1,2}$, Boyana Trifonova ${ }^{1,2}$, Ludmila Ivanova ${ }^{2}$, Lilia Dakovska ${ }^{1}$, Eugenia Mihailova $^{1}$ and \\ Mircho Vukov ${ }^{1}$
}

${ }^{1}$ Clinic of Endocrinology, University Hospital Sofiamed, Sofia, Bulgaria

${ }^{2}$ Faculty of Medicine, Sofia University Saint Kliment Ohridski, Sofia, Bulgaria

Citation: Anna-Maria Borissova, Boyana Trifonova, Ludmila Ivanova, Lilia Dakovska, Eugenia Mihailova and Mircho Vukov (2021). Frequency and characteristics of thyroid dysfunction in pregnant women - screening of 547 women in Bulgaria. Journal of Medical \& Clinical Research 6(1):351-357.

\section{Abstract}

The Recommendations of the European Thyroid Association'2014 have been widespread among the medical community for many years. In them as well as in the latest Recommendations of the American Thyroid Association'2017 the first recommendation is related to the development of population-based reference limits based on data from the local population. The aim is to study the current functional thyroid status in pregnant Bulgarian women and to carefully assess in the light of modern understandings the specific diagnostic and therapeutic approach for our population.

Material and Methods: The study was conducted as a cross-sectional multicenter population-based study, which included 547 pregnant women, mean age $30 \pm 5$ years. Fasting morning venous blood (TSH, FT4, TPOAb - determined by ECLIA method) and fresh morning urine sample (to determine urine iodine concentration) was taken, ultrasound examination of the thyroid gland was performed.

Results: Based on the accepted cut-off for TSH according to the Recommendations of ETA'2014, the studied pregnant women were divided into six groups: Subclinical and Clinical hypothyroidism; Subclinical and Clinical hyperthyroidism; Euthyroid; Low T4 syndrome. Almost 2/3 of pregnant women have TSH $2.5 \mathrm{mIU}$ / L. Undiagnosed hypothyroidism is present in 121 pregnant women (22\%), which is a bad feature of our health system. The data were analyzed in two TSH cut-offs (ETA'2014 and ATA'2017) and it was found that the increase in TSH cut-off for the first trimester did not change the absolute number of undiagnosed and untreated pregnant women with Clinical hypothyroidism, increasing 2.5 times its relative share, from $25.6 \%$ reaching $63.3 \%$ of all undiagnosed cases of hypothyroidism.

Conclusion: Increasing the cut-off of TSH would unrealistically calm and neglect the follow-up of the pregnant women which is very dangerous. Efforts should focus on early screening for verbally identified risk factors. Of course, it is necessary to develop a national standard for TSH, which would serve more accurately to assess the thyroid status of pregnant women in the Bulgarian population.

Keywords: Pregnancy, Thyroid Function, Evaluation Criteria, Population Specificity
ATA: American Thyroid Association mUIC: Median Urinary Iodine Concentration BMI: Body Mass Index ICP-MS: Inductively Coupled Plasma Mass Spectrometry ECLIA: Electro-Chemiluminescence Immunoassay SCHT: Subclinical Hypothyroidism 
CHT: Clinical Hypothyroidism

SCHyperT: Subclinical Hyperthyroidism

ChyperT: Clinical Hyperthyroidism

EuT: Euthyroid Person i.e. Healthy

LowT4: Low T4 syndrome

ICSI: Intracytoplasmic Semen Injection

\section{Introduction}

The Recommendations of the European Thyroid Association (ETA) from 2014 have been widely spread among the medical community for many years and the first points are: 1) The reference limits for each trimester of TSH, FT4 (total or free) should be established for each clinical laboratory. 2) If trimester-specific reference limits are not present, the following upper TSH reference values are recommended: first trimester $-2.5 \mathrm{mU} / \mathrm{L}$; second trimester - $3.0 \mathrm{mU} / \mathrm{L}$; third trimester - $3.5 \mathrm{mU} / \mathrm{L}[1]$.

In 2015, Medici M. et al. provided specific recommendations on how adequate reference limits can be established: selection of at least 400 pregnant women with first pregnancy, no previous thyroid disease, no use of thyroid-interfering drugs, no in vitro fertilisation (IVF) treatment, no TPOAb [2].

In the latest Recommendations of the American Thyroid Association (ATA) from 2017, the first recommendation is also related to the development of population-based reference limits based on assessment of local population data. These recommendations specify the requirements: to include only pregnant women without thyroid disease, at optimal iodine intake, negative TPOAb [3]. The ATA'2017 Recommendations suggested that population reference limits be established for trimesters and for FT4 [3]. The same Recommendations comment on the fact that during the first trimester the lower TSH reference limit decreases by approximately $0.4 \mathrm{mU}$ / L, while the upper one decreases by about $0.5 \mathrm{mU} / \mathrm{L}$. Usually for early pregnancy this corresponds to an upper reference limit for TSH - $4.0 \mathrm{mU} / \mathrm{L}$. This is applicable at the end of the first trimester (7-12 weeks), after which TSH gradually returns to the limits for non-pregnant women during the second and third trimesters [3].

Given the physiological changes in the level of thyroid hormones during pregnancy, it is necessary to define reference limits for this period in order to assess the functional status of the thyroid gland. For correct interpretation of the results it is necessary to update the data on iodine intake in pregnant women in Bulgaria. In the first part of our study, it was found that the median urinary iodine concentration (mUIC) for the study group of 537 pregnant women was $170 \mu \mathrm{g} / \mathrm{L}(95 \%$ CI 161 - 177). According to the accepted cut-off in pregnant women for normal UIC - median UIC values in the range 150-249 $\mu \mathrm{g} / \mathrm{L}$, our data show that the study group of pregnant women have normal UIC which guarantees the correct results of hormonal examinations of the thyroid gland [4-7]. We set ourselves the goal to study the current functional thyroid status in pregnant Bulgarian women and to carefully assess the specific diagnostic and therapeutic approach for our population in the light of modern understandings.

\section{Study Design}

The study was conducted as a cross-sectional multicenter population-based study and was conducted from September 25 to November 6, 2019 in ten regions of Bulgaria (Sofia, Samokov, Pir- dop, Smolyan, Gotse Delchev, Gabrovo, Troyan, Burgas, Stara Zagora, Pleven) and their adjacent towns and villages or a total of 84 settlements. We turned to 104 endocrinologists and gynecologists for cooperation, who invited more than 630 pregnant women to participate in the screening. Of these, 547 pregnant women $(86.8 \%)$ took part.

\section{Material and Methods}

We investigated 547 pregnant women, mean age $30 \pm 5$ years, median 30 years (min 18 - max 47 years) - 40\% (28 - 32 years), $23.4 \%$ (33 - 37 years), 21\% (23 - 27 years), $8.4 \%$ ( 38 - 42 years, $6 \%$ (18 - 22 years) and $1.1 \%$ (43 - 47 years). The examined pregnant women were distributed by trimesters as follows: first - 110 (20.1\%), second - 276 (50.5\%), third - 161 (29.4\%). All participants signed informed consent, confirmed by the local Ethics Commission at Sofiamed University Hospital, Sofia University "Saint Kliment Ohridski". It was prepared in accordance with the ethical standards according to the Helsinki Declaration-1964 and later additions [8]. Each pregnant woman filled in a questionnaire with the assistance of a specially designated medical person from the "face to face" team in order to correctly collect data on pregnancy history, intake of combined vitamins and minerals (including iodine) or other medications by type and dose, available thyroid or other diseases. Pregnant women were included in the Screening at random without pre-selection and 458 of all 547 (83.7\%) took medication. Basically in $49.5 \%$ (271/547) of the cases these were combined vitamins with minerals (including iodine) taken alone or together with other medications. The most common drugs were magnesium, folic acid and iron (57.1\%), while other drugs were given to individual pregnant women in order to preserve the pregnancy and bring it to a successful conclusion - spasmolytics, progestins, anticoagulants. Levothyroxine substitution or thyrostatic treatment for known thyroid disease was found in 77 (14.1\%) of pregnant women. Over $98 \%$ of households use iodized salt in Bulgaria. All participants were Caucasian, with no evidence of liver or kidney disease or evidence of malabsorption. Pregnant women had followed their usual daily routine in previous months.

After completing the personal Questionnaire, the current weight and height of each pregnant woman were measured and filled in the Questionnaire together with the weight before pregnancy. The body mass index (BMI - $\mathrm{kg} / \mathrm{m} 2$ ) before pregnancy and the current one at the time of the study were calculated.

\section{Ultrasound examination}

To determine the volume of the thyroid gland, an ultrasound examination was performed with a Digital Color Doppler Diagnostic Scanner, C5 Ex (Shenzhen Landwind Medical Industry, China). According to a standard formula, the volume of the thyroid gland in $\mathrm{mL}$ was calculated $[9,10]$.

\section{Urinary iodine concentration determination}

Pregnant women gave a single portion of the morning fresh midstream urine $\sim 20 \mathrm{ml}$ using clean plastic cups to test iodine. The samples were immediately transported at room temperature in neutral monocuvets to the Central Laboratory (for transport shorter than $8 \mathrm{~h}$, they were transported in room temperature, which does not influence their quality) and the aliquots of all urine samples were frozen at $-20 \mathrm{o}$ until analysis. The next day in a special container, the frozen samples were transported to Limbach laboratory 
in Heidelberg, Germany. The analysis was performed using the accredited inductively coupled plasma mass spectrometry (ICPMS) method with the following characteristics: linearity in the range of $0-4000 \mu \mathrm{g} / \mathrm{l}$, precision in the series at $304 \mathrm{mcg} / \mathrm{l} \mathrm{RSD}$ $0.8 \%$, inter-assay SNU $=304 \mu \mathrm{g} / 1,15$ shifts, RSD 4.5\%; accuracy percentage deviation from adjusted nominal value of the certified reference material SeronormTM Trace Elements urine (SNU) (304 $\mu \mathrm{g} / 1): 4.0 \%$ (data set $=4 \times 12)$, recovery $104 \%$. The results are in $\mu \mathrm{g} / \mathrm{L}$.

\section{Laboratory analysis}

Laboratory analysis of all blood samples was performed in a Central laboratory on the day of blood sampling in the morning on an empty stomach. Serum was quantified on a Cobas e601: TSH analyzer with the ECLIA sandwich method (reference range 0.27-4.2 $\mathrm{mIU} / \mathrm{L}$ ); free thyroxine (FT4) with a competitive ECLIA method (reference limits 9.3-17.0 ng / L) and TPOAb with a competitive ECLIA method (reference limits $<34 \mathrm{IU} / \mathrm{mL}$ ).

\section{The Statistical Analysis}

The statistical analysis was performed using standard SPSS 13.0 for Windows: descriptive statistics (mean, medians, standard deviation), correlation analysis and analysis of variance (ANOVA, post-hoc test - with Bonferroni alpha correction), using parametrical and non-parametrical methods , including - Chi-Square Test, Fisher's Exact Test, Kolmogorov-Smirnov, Shapiro-Wilk Tests, Levene's Test for Equality of Variances, Student's t-test, Kruskal-Wallis test and Mann -Whitney test. All quantitative variables were presented as mean with standard deviation, median or percentage (unless specified otherwise), p values below 0.05 were accepted as statistically significant.

\section{Results}

The present analyzes were made on the basis of the ETA Recommendations from 2014. After that, a comparison was made with the ATA Recommendations from 2017. The complex clinical assessment of the functional state of the thyroid gland of the examined pregnant women is complex and is made on the basis of the data for TSH, FT4 and thyroid peroxidase antibodies (TPOAb), as well as the ultrasound structure of the thyroid gland, evidence of a family history of thyroid pathology, the presence of a known thyroid disease or treatment for such disease. Based on the accepted cut-off for TSH according to the ETA Recommendations from 2014, the studied pregnant women were divided into six groups: 1 . Subclinical hypothyroidism (SCHT); 2. Clinical hypothyroidism (CHT); 3. Subclinical hyperthyroidism (SCHyperT); 4. Clinical hyperthyroidism (CHyperT); 5. Euthyroid State (EuT); 6. Low T4 syndrome (LowT4). It turns out that $27.6 \%$ (n-151) of pregnant women have impaired thyroid function. In the following table 1 we present the distribution of the examined pregnant women according to the functional status of the thyroid gland.
Table 1. Distribution according to the complex assessment of thyroid function in 547 pregnant women

\begin{tabular}{|l|c|}
\hline Type of thyroid function & Number (\%) \\
\hline Subclinical Hypothyroidism & $110(20.1 \%)$ \\
\hline Clinical Hypothyroidism & $34(6.2 \%)$ \\
\hline Subclinical Hyperthyroidism & $5(0.9 \%)$ \\
\hline Clinical Hyperthyroidism & $2(0.4 \%)$ \\
\hline Euthyroid State & $350(64 \%)$ \\
\hline LowT4 & $46(8.4 \%)$ \\
\hline Total & $547(100 \%)$ \\
\hline
\end{tabular}

For each of the six identified groups, the TSH level (mean $\pm \mathrm{SD}$, median) is presented in the following table 2 .

Table 2. TSH level (mean \pm SD, median) for each of the 6 functional groups of the 547 pregnant women

\begin{tabular}{|l|c|c|c|}
\hline Type thyroid function & Mean & $\begin{array}{c}\text { Std. } \\
\text { Deviation }\end{array}$ & Median \\
\hline SCHT & 4.64 & 1.54 & 4.26 \\
\hline CHT & 5.21 & 3.93 & 4.02 \\
n-34 & 0.026 & 0.02 & 0.02 \\
SCHyperT & 0.01 & 0.00 & 0.01 \\
\hline CHyperT & 2.08 & 0.81 & 2.12 \\
\hline n-2 & 2.77 & 1.84 & 2.53 \\
\hline EuT & 2.13 & 0.78 & 2.20 \\
\hline Low T4 & & & \\
\hline Total & & & \\
\hline
\end{tabular}


The number and frequency of the respective functional thyroid disorder at different levels of UIC - low, normal, over-optimal is presented in Table 3.

Table 3. Frequency of the six functional groups according to the level of UIC

\begin{tabular}{|c|c|c|c|}
\hline $\begin{array}{l}\text { Groups } \\
\text { according } \\
\text { UIC }\end{array}$ & $\begin{array}{l}<150 \\
\mu \mathrm{g} / \mathrm{L}\end{array}$ & $\begin{array}{l}150-249 \\
\mu \mathrm{g} / \mathrm{L}\end{array}$ & $\begin{array}{l}>250 \\
\mu \mathrm{g} / \mathrm{L}\end{array}$ \\
\hline & Number (\%) & Number (\%) & Number (\%) \\
\hline SCHT & $\begin{array}{c}40 \\
(18.1 \%) \\
\end{array}$ & $\begin{array}{c}43 \\
(20.4 \%) \\
\end{array}$ & $\begin{array}{c}22 \\
(21 \%) \\
\end{array}$ \\
\hline CHT & $\begin{array}{c}16 \\
(7.2 \%)\end{array}$ & $\begin{array}{c}13 \\
(6.2 \%)\end{array}$ & $\begin{array}{c}5 \\
(4.8 \%)\end{array}$ \\
\hline SCHyperT & $\begin{array}{c}2 \\
(0.9 \%) \\
\end{array}$ & $\begin{array}{c}1 \\
(0.5 \%) \\
\end{array}$ & $\begin{array}{c}1 \\
(0.9 \%)\end{array}$ \\
\hline CHyperT & 0 & $\begin{array}{c}2 \\
(0.9 \%)\end{array}$ & 0 \\
\hline EuT & $\begin{array}{c}144 \\
(65.2 \%) \\
\end{array}$ & $\begin{array}{c}137 \\
(64.9 \%) \\
\end{array}$ & $\begin{array}{c}65 \\
(61.9 \%) \\
\end{array}$ \\
\hline Low T4 & $\begin{array}{c}19 \\
(8.6 \%)\end{array}$ & $\begin{array}{c}15 \\
(7.1 \%)\end{array}$ & $\begin{array}{c}12 \\
(11.4 \%)\end{array}$ \\
\hline Total & $\begin{array}{c}221 \\
(100 \%)\end{array}$ & $\begin{array}{c}211 \\
(100 \%)\end{array}$ & $\begin{array}{c}105 \\
(100 \%)\end{array}$ \\
\hline
\end{tabular}

The analysis showed that increased TSH levels according to the above criteria were present in $144(26.32 \%)$ pregnant women - 110 with SCHT and 34 with CHT. It turns out that almost $2 / 3$ of pregnant women or $73.7 \%(n-403)$ have TSH $<2.5$ and $78 \%(n-425)$ with $\mathrm{TSH}<3.5$. The following Table 4 presents the distribution of pregnant women at different cut-offs in TSH levels.

Table 4. Distribution of pregnant women by trimesters and according to different cut-offs in the level of TSH.

\begin{tabular}{|l|c|c|c|c|}
\hline Trimester & TSH $>\mathbf{2 , 5}$ & TSH $>\mathbf{3 . 0}$ & TSH $>\mathbf{3 . 5}$ & TSH $>$ 4.0 \\
\hline $\begin{array}{l}\text { First } \\
\text { n-110 }\end{array}$ & $\begin{array}{c}30 \\
(27.3 \%)\end{array}$ & $\begin{array}{c}29 \\
(26.4 \%)\end{array}$ & $\begin{array}{c}21 \\
(19.1 \%)\end{array}$ & $\begin{array}{c}13 \\
(11.8 \%)\end{array}$ \\
\hline $\begin{array}{l}\text { Second } \\
\text { n-276 }\end{array}$ & $\begin{array}{c}83 \\
(30.1 \%)\end{array}$ & $\begin{array}{c}83 \\
(30.1 \%)\end{array}$ & $\begin{array}{c}72 \\
(26.1 \%)\end{array}$ & $\begin{array}{c}48 \\
(17.4 \%)\end{array}$ \\
\hline Third & 31 & 31 & 29 & 21 \\
n-161 & $(19.2 \%)$ & $(19.2 \%)$ & $(18 \%)$ & $(13 \%)$ \\
\hline Total & 144 & 143 & 122 & 82 \\
n-547 & $(26.3 \%)$ & $(26.1 \%)$ & $(22.3 \%)$ & $(14.99 \%)$ \\
\hline
\end{tabular}

It was found that 77 pregnant women were taking drugs related to the thyroid gland. Of these, 76 were taking Levothyroxine for hypothyroidism, and one pregnant woman was taking thyrostatic. The following Table 5 presents the distribution of pregnant women under treatment according to TSH levels.
Table 5. Distribution of pregnant women under treatment according to TSH level during screening

\begin{tabular}{|l|c|c|c|c|c|}
\hline $\begin{array}{l}\text { Type } \\
\text { thyroid } \\
\text { function }\end{array}$ & SCHT & CHT & CHyperT & EuT & $\begin{array}{l}\text { Total } \\
\text { under } \\
\text { treatment }\end{array}$ \\
\hline $\begin{array}{l}\text { Total } \\
\text { number } \\
(\%)\end{array}$ & $\begin{array}{c}20 \\
(26 \%)\end{array}$ & $\begin{array}{c}3 \\
(3.9 \%)\end{array}$ & $\begin{array}{c}1 \\
(1.3 \%)\end{array}$ & $\begin{array}{c}53 \\
(68.8 \%)\end{array}$ & $\begin{array}{c}77 \\
(100 \%)\end{array}$ \\
\hline $\begin{array}{l}\text { Second } \\
\text { trimester }\end{array}$ & $\begin{array}{c}3 \\
(15 \%)\end{array}$ & $\begin{array}{c}1 \\
(33.3 \%)\end{array}$ & $\begin{array}{c}1 \\
(100 \%)\end{array}$ & $\begin{array}{c}11 \\
(20.8 \%)\end{array}$ & $\begin{array}{c}16 \\
(20.8 \%)\end{array}$ \\
\hline $\begin{array}{l}\text { Second } \\
\text { trimester }\end{array}$ & $\begin{array}{c}14 \\
(70 \%)\end{array}$ & $\begin{array}{c}2 \\
(66.7 \%)\end{array}$ & 0 & $\begin{array}{c}28 \\
(52.8 \%)\end{array}$ & $\begin{array}{c}44 \\
(57.1 \%)\end{array}$ \\
\hline $\begin{array}{l}\text { Third } \\
\text { trimester }\end{array}$ & $\begin{array}{c}3 \\
(15 \%)\end{array}$ & 0 & 0 & $\begin{array}{c}14 \\
(26.4 \%)\end{array}$ & $\begin{array}{c}17 \\
(22 \%)\end{array}$ \\
\hline
\end{tabular}

\section{Hyperthyroidism}

Seven $(1.3 \%)$ pregnant women with hyperthyroidism were identified in the screening. Of these, $3(42.8 \%)$ were aware of the disorder, but only one was undergoing thyrostatic treatment. In pregnant woman number 1 persisted CHyperT, TPOAb (+). In pregnant woman number 2 , thyrostatic treatment had achieved the desired level of thyroid hormones for pregnancy (upper-limit normal FT4, TSH - slightly suppressed), TPOAb (-). In both women, the ultrasound thyroid finding corresponded to autoimmune thyroid disease. Pregnant woman number 3 was with SCHyperT, with ultrasound-proven thyroid formation, TPOAb (-), family history with nodular goiter.

Four (58.2\%) pregnant women had a newly diagnosed thyroid dysfunction. Pregnant women numbers 4, 5 and 6 were with SCHyperT, ultrasound detected formations of the thyroid gland, with a family history of nodular goiter (in two of them). The last pregnant woman number 7 had mild clinical hyperthyroidism, TPOAb $(-)$, no ultrasound structural changes, no family history. In the last case, there may also be Gestational thyrotoxicosis due to a stronger thyroid response to the effects of hCG in early pregnancy. In principle, the most common cause of hyperthyroidism at a young age is Graves' disease - $0.2 \%$ [11], which requires additional research (TSH-RAb), and in second place is the nodular goiter. All cases were handed over for follow-up to their personal endocrinologists resp. gynecologists.

\section{Hypothyroidism}

Levothyroxine treatment in $69.7 \%(53 / 76)$ of the pregnant women led to normal hormonal levels, but in the remaining 30.3\% (23/76) of the pregnant women hypothyroidism persisted. Thus, 53 pregnant women with normal thyroid hormones (due to the successful treatment with Levothyroxine) should be added to the 144 pregnant women with elevated TSH levels. In fact, it turns out that the total number of pregnant women with hypothyroidism is $197 / 547$ (36\%). In summary, the analysis of all 197 pregnant women with hypothyroidism showed that $61.4 \%(121 / 197)$ were newly diagnosed and without treatment - $90(74.38 \%)$ pregnant women were 
with SCHT and $31(25.62 \%)$ pregnant women were with CHT. Another 23 were being treated but remain hypothyroid. It can be summarized that 121 pregnant women had newly diagnosed hypothyroidism, 23 were known to have failed treatment and 53 were also known and successfully treated for hypothyroidism.

By trimesters, the distribution of pregnant women under treatment (n-53) who achieved euthyroid status is presented in Table 6.

Table 6. Pregnant women undergoing treatment achieved euthyroid status divided by trimesters

\begin{tabular}{|l|c|l|c|}
\hline Trimester & $\begin{array}{l}\mathbf{5 3}(\mathbf{9 . 6 9 \%}) \\
\text { pregnants } \\
\text { in euthyroid } \\
\text { state }\end{array}$ & $\begin{array}{l}\text { Number (\%) } \\
\text { of pregnant } \\
\text { women per } \\
\text { trimester }\end{array}$ & $\begin{array}{l}\text { Total } \\
\text { number (\%) } \\
\text { of pregnant } \\
\text { women } \\
(\mathbf{n}-\mathbf{5 4 7 )}\end{array}$ \\
\hline $\begin{array}{l}\text { First } \\
(\mathrm{n}-110)\end{array}$ & $\begin{array}{c}11 / 53 \\
(20.7 \%)\end{array}$ & $\begin{array}{l}11 / 110 \\
(10 \%)\end{array}$ & $\begin{array}{l}11 / 547 \\
(2.0 \%)\end{array}$ \\
\hline $\begin{array}{l}\text { Second (n- } \\
276)\end{array}$ & $\begin{array}{l}28 / 53 \\
(52.8 \%)\end{array}$ & $\begin{array}{l}28 / 276 \\
(10.1 \%)\end{array}$ & $\begin{array}{l}28 / 547 \\
(5.1 \%)\end{array}$ \\
\hline $\begin{array}{l}\text { Third } \\
(\mathrm{n}-161)\end{array}$ & $\begin{array}{c}14 / 53 \\
(26.4 \%)\end{array}$ & $\begin{array}{l}14 / 161 \\
(8.7 \%)\end{array}$ & $\begin{array}{l}14 / 547 \\
(2.6 \%)\end{array}$ \\
\hline
\end{tabular}

By trimesters, the distribution of pregnant women under treatment (n-23) who did not achieve euthyroid status is presented in Table 7.

Table 7. Pregnant women under treatment who remained hypothyroid, divided by trimesters

\begin{tabular}{|l|c|c|c|}
\hline Trimester & $\begin{array}{l}\mathbf{2 3}(\mathbf{4 . 2 \% )} \\
\text { pregnants } \\
\text { in a } \\
\text { hypothyroid } \\
\text { state }\end{array}$ & $\begin{array}{l}\text { Number (\%) } \\
\text { of pregnant } \\
\text { women per } \\
\text { trimester }\end{array}$ & $\begin{array}{l}\text { Total } \\
\text { number (\%) } \\
\text { of pregnant } \\
\text { women } \\
(\mathbf{n}-547)\end{array}$ \\
\hline $\begin{array}{l}\text { First } \\
(\mathrm{n}-110)\end{array}$ & $\begin{array}{l}/ 23 \\
(17.4 \%)\end{array}$ & $\begin{array}{l}4 / 110 \\
(3.6 \%)\end{array}$ & $\begin{array}{l}4 / 547 \\
(0.7 \%)\end{array}$ \\
\hline $\begin{array}{l}\text { Second } \\
(\mathrm{n}-276)\end{array}$ & $\begin{array}{l}16 / 23 \\
(69.6 \%)\end{array}$ & $\begin{array}{l}16 / 276 \\
(5.8 \%)\end{array}$ & $\begin{array}{l}16 / 547 \\
(2.9 \%)\end{array}$ \\
\hline $\begin{array}{l}\text { Third } \\
(\mathrm{n}-161)\end{array}$ & $\begin{array}{c}3 / 23 \\
(13.0 \%)\end{array}$ & $\begin{array}{c}3 / 161 \\
(1.9 \%)\end{array}$ & $\begin{array}{l}3 / 547 \\
(0.5 \%)\end{array}$ \\
\hline
\end{tabular}

By trimesters, the distribution of pregnant women with newly diagnosed hypothyroidism and without treatment (n-121) is presented in Table 8, both in general and separately - SCHT (n-90) and CHT (n-31).
Table 8. Pregnant women with newly diagnosed hypothyroidism (SCHT and CHT) and without treatment - total and by trimesters

\begin{tabular}{|c|c|c|c|}
\hline \multicolumn{4}{|c|}{$\begin{array}{c}\text { Total (n-121, 22.1\%) newly diagnosed pregnant women } \\
\text { with hypothyroidism }\end{array}$} \\
\hline Trimester & $\begin{array}{l}121 \\
\text { pregnants } \\
\text { in a } \\
\text { hypothyroid } \\
\text { state }\end{array}$ & $\begin{array}{l}\text { Number of } \\
\text { pregnant } \\
\text { women per } \\
\text { trimester }\end{array}$ & $\begin{array}{l}\text { Total number } \\
\text { of pregnant } \\
\text { women } \\
(n-547)\end{array}$ \\
\hline $\begin{array}{l}\text { First } \\
(n-110)\end{array}$ & $\begin{array}{l}26 / 121 \\
(21.5 \%)\end{array}$ & $\begin{array}{l}26 / 110 \\
(23.6 \%)\end{array}$ & $\begin{array}{l}26 / 547 \\
(47.7 \%)\end{array}$ \\
\hline $\begin{array}{l}\text { Second (n- } \\
276)\end{array}$ & $\begin{array}{l}67 / 121 \\
(55.4 \%)\end{array}$ & $\begin{array}{l}67 / 276 \\
(24.3 \%)\end{array}$ & $\begin{array}{l}67 / 547 \\
(12.2 \%)\end{array}$ \\
\hline $\begin{array}{l}\text { Third } \\
(n-161)\end{array}$ & $\begin{array}{l}28 / 121 \\
(23.1 \%)\end{array}$ & $\begin{array}{l}28 / 161 \\
(17.4 \%\end{array}$ & $\begin{array}{l}28 / 547 \\
(5.1 \%)\end{array}$ \\
\hline \multicolumn{4}{|c|}{ Subclinical Hypothyroidism (n-90, 16.4\%) } \\
\hline Trimester & $\begin{array}{l}90 \text { pregnants } \\
\text { in a } \\
\text { hypothyroid } \\
\text { state }\end{array}$ & $\begin{array}{l}\text { Number of } \\
\text { pregnant } \\
\text { women per } \\
\text { trimester }\end{array}$ & $\begin{array}{l}\text { Total } \\
\text { number of } \\
\text { pregnant } \\
\text { women } \\
\text { (n-547) }\end{array}$ \\
\hline $\begin{array}{l}\text { First } \\
(n-110)\end{array}$ & $\begin{array}{l}25 / 90 \\
(27.8 \%)\end{array}$ & $\begin{array}{l}25 / 110 \\
(22.7 \%)\end{array}$ & $\begin{array}{l}25 / 547 \\
(4.6 \%)\end{array}$ \\
\hline $\begin{array}{l}\text { Second } \\
(n-276)\end{array}$ & $\begin{array}{l}51 / 90 \\
(56.7 \%)\end{array}$ & $\begin{array}{l}51 / 276 \\
(18.5 \%)\end{array}$ & $\begin{array}{l}51 / 547 \\
(9.3 \%)\end{array}$ \\
\hline $\begin{array}{l}\text { Third } \\
(n-161)\end{array}$ & $\begin{array}{l}14 / 90 \\
(15.5 \%)\end{array}$ & $\begin{array}{l}14 / 161 \\
(8.7 \%)\end{array}$ & $\begin{array}{l}14 / 547 \\
(2.6 \%)\end{array}$ \\
\hline \multicolumn{4}{|c|}{ Clinical Hypothyroidism - n-31 (5.7\%) } \\
\hline Trimester & $\begin{array}{l}31 \text { pregnants } \\
\text { in a } \\
\text { hypothyroid } \\
\text { state }\end{array}$ & $\begin{array}{l}\text { Number of } \\
\text { pregnant } \\
\text { women per } \\
\text { trimester }\end{array}$ & $\begin{array}{l}\text { Total } \\
\text { number of } \\
\text { pregnant } \\
\text { women } \\
\text { (n-547) }\end{array}$ \\
\hline $\begin{array}{l}\text { First } \\
(n-110)\end{array}$ & $\begin{array}{l}1 / 31 \\
(3.2 \%)\end{array}$ & $\begin{array}{l}1 / 110 \\
(0.9 \%)\end{array}$ & $\begin{array}{l}1 / 547 \\
(0.2 \%)\end{array}$ \\
\hline $\begin{array}{l}\text { Second (n- } \\
276)\end{array}$ & $\begin{array}{l}16 / 31 \\
(51.6 \%)\end{array}$ & $\begin{array}{l}16 / 276 \\
(5.8 \%)\end{array}$ & $\begin{array}{l}16 / 547 \\
(2.9 \%)\end{array}$ \\
\hline $\begin{array}{l}\text { Third } \\
\text { (n-161) }\end{array}$ & $\begin{array}{l}14 / 31 \\
(45.2 \%)\end{array}$ & $\begin{array}{c}14 / 161 \\
(8.7 \%)\end{array}$ & $\begin{array}{c}14 / 547 \\
(2.6 \%)\end{array}$ \\
\hline
\end{tabular}

We present a comparative table 9 on the distribution of the studied pregnant women according to the different cut-offs for TSH of the two current Recommendations - ETA'2014 and ATA'2017. 
Table 9. Incidence of hypothyroidism according to the Recommendations of ETA'2014 and ATA'2017

\begin{tabular}{|l|c|c|c|c|}
\hline $\begin{array}{l}\text { Trimester } \\
\text { cut-off } \\
\text { TSH }\end{array}$ & $\begin{array}{c}\text { First } \\
(\mathbf{n}-110)\end{array}$ & $\begin{array}{c}\text { Second } \\
(\mathbf{n}-276)\end{array}$ & $\begin{array}{c}\text { Third } \\
(\mathbf{n}-161)\end{array}$ & $\begin{array}{c}\text { Total } \\
(\mathbf{n}-547)\end{array}$ \\
\hline $\begin{array}{l}\text { I }>2.5 ; \\
\text { II }>3.0 ; \\
\text { III }>3.5\end{array}$ & $\begin{array}{l}30 \\
(27.3 \%)\end{array}$ & $83(30 \%)$ & $29(18 \%)$ & $\begin{array}{c}142 \\
(25.95 \%)\end{array}$ \\
\hline $\begin{array}{l}\text { I }>4.0 ; \\
\text { II }>3.0 ; \\
\text { III }>3.5\end{array}$ & $\begin{array}{c}13 \\
(11.8 \%)\end{array}$ & $\begin{array}{c}83 \\
(30 \%)\end{array}$ & $\begin{array}{c}29 \\
(18 \%)\end{array}$ & $\begin{array}{c}125 \\
(22.85 \%)\end{array}$ \\
\hline
\end{tabular}

\section{Discussion}

The last table 9 shows that according to ATA'2017 Recommendations the need to start replacement therapy in the first trimester will decrease by more than $50 \%$, with the situation unchanged for the next trimesters. In particular, it should be noted that the ATA'2017 Recommendations have several exceptions to the recommendation to include Levothyroxine at TSH $4 \mathrm{mIU} / \mathrm{L}$. These are cases of $\mathrm{TPOAb}(+)$ pregnant women with $\mathrm{TSH}>2.5 \mathrm{mIU} / \mathrm{L}$ due to observational studies demonstrating a higher risk of miscarriage and premature birth with TPOAb $(+)$ and TSH $>2.5 \mathrm{mIU} / \mathrm{L}[12,13]$. The second exception in the ATA'2017 Recommendations is related to women undergoing IVF or intracytoplasmic semen injection (ICSI), for whom Levothyroxine must be included in the SCHT to maintain TSH $<2.5 \mathrm{mIU} / \mathrm{L}$ (strong ATA recommendation).

Maraka S. et al. 2019 [14], analyzed the initiation of Levothyroxine in pregnant women for the period 2010-2014 in several US states. In summary, $15 \%$ of the cases started taking Levothyroxine at TSH $2.5-10 \mathrm{mIU} / \mathrm{L}$ and in $42 \%$ of cases - at TSH $4.0-10$ $\mathrm{mIU} / \mathrm{L}$. The factors that determine the decision are the region, the ethnicity, the medical practice, the change of perceptions over time. Tim IM. Korevaar, 2019 [15] analyzes the work of Maraka S. et al. and Tim I.M. Korevaar concludes that the study has significant weaknesses. It includes only pregnant women with health insurance from private insurers and the health system Medicare. There were no uninsured women or women with public health insurance. This strongly emphasized that socio-economic factors are a strong determinant for initiating treatment with Levothyroxine during pregnancy. In the analysis of Tim I.M. Korevaar adds that there are 4 million births per year in the United States, and about $15 \%$ of all pregnant women have TSH $>2.5 \mathrm{mIU} / 1$ (the implication is that with early inclusion of Levothyroxine at TSH $>2.5$ $\mathrm{mIU} / \mathrm{L}$, there are about 600,000 new pregnant women with the potential to take Levothyroxine and private insurers probably have this fact in mind).

The latest Recommendations of the American Thyroid Association [3] state precisely -

1. ATA'2017 considers that Levothyroxine may be given to pregnant women:

- $\quad$ TPOAb $(+)$ and TSH $>2.5 \mathrm{mIU} / \mathrm{L}$

- $\mathrm{TPOAb}(-)$ and TSH $>4 \mathrm{mIU} / \mathrm{L}$

2 ATA'2017 recommends Levothyroxine in pregnant women:

- $\mathrm{TPOAb}(+)$ and TSH $>4 \mathrm{mIU} / \mathrm{L}$

- $\mathrm{TPOAb}(-)$ and TSH $>10 \mathrm{mIU} / \mathrm{L}$
How can we actually read these recommendations, taking into account the specific data and circumstances in our country? The following table shows the Bulgarian data, which compare the results of the two proposed cut-offs for TSH. The increase in the share of those treated and decrease in the share of those newly diagnosed with hypothyroidism. It has been demonstrated clearly that if we have the same absolute number of cases with CTH (n31 ), their relative share has increased more than twice, and from $25.6 \%$ has reached $63.3 \%$ of all cases which were not diagnosed (table 10).

Table 10. Distribution of cases of newly diagnosed hypothyroidism without treatment with different cut-off TSH

\begin{tabular}{|l|l|l|l|}
\hline $\begin{array}{l}\text { TSH cut-off } \\
\text { according to } \\
\text { ETA'2014 } \\
\text { Recommen- } \\
\text { dations }\end{array}$ & $\begin{array}{l}\text { With } \\
\text { hypothyroidism } \\
\text { total }\end{array}$ & $\begin{array}{l}\text { With } \\
\text { Levothyroxine } \\
\text { Treatment }\end{array}$ & $\begin{array}{l}\text { Newly } \\
\text { diagnosed } \\
\text { hypothyroidism } \\
\text { without } \\
\text { treatment }\end{array}$ \\
\hline $\begin{array}{l}\text { In the } \\
\text { euthyroid } \\
\text { state }\end{array}$ & $197(36.0 \%)$ & $76(38.6 \%)$ & $121(61.4 \%)$ \\
\hline $\begin{array}{l}\text { In a } \\
\text { hypothyroid } \\
\text { state }\end{array}$ & $53(69.7 \%)$ & \\
\hline $\begin{array}{l}\text { TSH cut-off } \\
\text { according to } \\
\text { ATA'2017 } \\
\text { Recommend- } \\
\text { ations }\end{array}$ & $\begin{array}{l}\text { With } \\
\text { total }\end{array}$ & $23(30.3 \%)$ & $\begin{array}{l}\text { SCHT - } 90 \\
(74.4 \%) \\
\text { CHT - } 31 \\
(25.6 \%)\end{array}$ \\
\hline & $125(22.8 \%)$ & $76(60.8 \%)$ & $\begin{array}{l}\text { Newly } \\
\text { diagnosed } \\
\text { hypothyroidism } \\
\text { without } \\
\text { treatment }\end{array}$ \\
\hline $\begin{array}{l}\text { In the } \\
\text { euthyroid } \\
\text { state }\end{array}$ & & $\begin{array}{l}\text { Wevothyroxidh }(39.2 \%) \\
\text { Treatment }\end{array}$ \\
\hline $\begin{array}{l}\text { In a } \\
\text { hypothyroid } \\
\text { state }\end{array}$ & & $57(75 \%)$ & \\
\hline
\end{tabular}

\section{Limitations}

However, this study has some limitations. Essentially it is a cross-sectional multicenter population-based study. This is how the current picture of the functional characteristics of the thyroid gland in a pregnant woman in Bulgaria came about. But the information would be very useful in the prospective follow-up of cases with and without functional thyroid disorders during pregnancy, as well as immunological dynamics. This would outline more clearly and categorically the diagnostic and therapeutic behavior of pregnant women in our country.

\section{Conclusion}

The analysis of all 197 pregnant women with hypothyroidism showed that 121 (61.4\%) were not treated - 2/3 with SCHT and $1 / 3$ with CHT. It is these 121 pregnant women who actually have 
newly diagnosed hypothyroidism, which makes $22.1 \%$ of all pregnant women. This is a significant percentage and requires a careful approach. The choice of criteria for assessing the functional status of the thyroid gland should take into account the local features of timely diagnosis, the possibilities for frequent control examinations, the inclusion of adequate treatment and adherence to it. It is very impressive that $2 / 3$ of those who have failed treatment with Levothyroxine are in the second trimester, which may be due to inadequate dose or non-adherence to treatment. Our data showed that not only the share of newly diagnosed hypothyroid pregnant women is too high - $121(22.1 \%)$, but also the share of pregnant women with CHT-31/121 (25.6\%). The increase in TSH cut-off for the first trimester did not change this absolute number of undiagnosed and untreated pregnant women with CHT, but increased 2.5 times its relative share - from $25.6 \%$ to $63.3 \%$ of all undiagnosed cases of hypothyroidism. It should be borne in mind that in the group with CHT of 34 pregnant women only 3 were already diagnosed and treated, but it does not remove them from the status of CHT, ie. it was not adequate. It turns out that $91.2 \%$ of patients with CHT are newly diagnosed and this is an extremely poor testament to our health system. In fact, it should be emphasized that is difficult to solve and the problem, which is related to the early diagnosis and regular follow-up of women, especially in the first half of their pregnancy. Increasing the cut-off of TSH would unrealistically calm and neglect the follow-up of the pregnant women which is very dangerous. Efforts should focus on early screening for verbally identified risk factors. Of course, it is necessary to develop a national standard for TSH, which would serve more accurately to assess the thyroid status of pregnant women in Bulgaria.

\section{Acknowledgements}

The authors thank the endocrinologists and obstetrician/gynecologists who provided local support: V. Jotova (Troyan), S. Dimitrova (Gabrovo), Anchev (Gabrovo), Mitev (Gabrovo), A. Popov (Goce Delchev), A. Andreev (Samokov), E. Apostolova (Smolyan), M. Hubshev (Smolyan), S. Dimitrov (Pirdop), R. Naumovska (Pleven), M. Manuelyan (Burgas), K. Kirovakov (Burgas), T. Gabrovska (Burgas), M. Angelova (Stara Zagora), K. Venkova (Sofia), R. Velev (Sofia), I. Sigridov (Sofia), B. Bogoslovova (Sofia) ... total 104 specialists in the country. Technical support: T. Kornilova (Sofia), Z. Metodieva (Sofia), J. Georgieva (Sofia), H. Atanasova (Burgas), I. Ilieva (Stara Zagora).

This work was supported by grants from the Bulgarian Society of Endocrinology as part of the National Epidemiological Program for Pregnant Women in Bulgaria 2019.

\section{References}

1. Lazarus J, Brown R.S, Daumerie C, Hubalewska-Dydejczyk A, Negro R, Vaidya B (2014) 2014 European Thyroid Association Guidelines for the Management of Subclinical Hypothyroidism in Pregnancy and in Children. Eur Thyroid J 3: 76-94. DOI: $10.1159 / 000362597$.

2. Medici M, Korevaar TI, Visser WE, Visser TJ, Peeters RP (2015) Thyroid function in pregnancy: what is normal? Clin Chem. 61 (5): 704-713.
3. Alexander EK, Pearce EN, Brent GA, Brown RS, Chen H, Dosiou C, Grobman WA, Laurberg P, Lazarus JH, Mandel SJ (2017). 2017 Guidelines of the American Thyroid Association for the diagnosis and Management of Thyroid Disease during Pregnancy and the postpartum. Thyroid. 27 (3): 315-389.

4. Iodine status worldwide: WHO global database on iodine deficiency. Geneva: World Health Organization, 2006.

5. World Health Organization, United Nations Children's Fund, International Council for Control of Iodine Deficiency Disorders. Assessment of iodine deficiency disorders and monitoring their elimination. A guide for programme managers. Geneva: WHO, 2007.

6. Borissova A-M, Ivanova L, Trifonova B, Dakovska L, Mihailova E, Vukov M (2020) Iodine Status of Pregnant Women in Bulgaria. European Journal of Preventive Medicine (EJPM) 8(4): 43-47.

7. Borissova A-M, Ivanova L, Trifonova B, Dakovska L, Mihailova E, Vukov (2020). Urine Iodine Concentration, TPOAb, Thyroid Hormones in Pregnant Bulgarian women - Results of a Screening Study. Endocrinologia 25(3): 175-189.

8. World Medical Association (2013) Declaration of Helsinki: Ethical Principles for Medical Research Involving $\mathrm{Hu}-$ man Subjects. JAMA. 310 (20): 2191-2194. doi:10.1001/ jama.2013.28105).

9. Brunn J, Block U, Ruf G, Bos I, Kunze WP, Scriba PC (1981) Volumetric analysis of thyroid lobes by real-time ultrasound. Dtsch Med Wochenschr. 106: 1338-1340.

10. Zimmermann MB, Hess S.Y, Molinari L, de Benoist B, Delange F, Braverman L.E, Fujieda K, Ito Y, Jooste P.L, Moos K, Jooste P.L, Pearce E.N, Pretell E.A, Shishiba Y (2004) New reference values for thyroid volume by ultrasound in iodine sufficient school children: a World Health Organization / Nutrition for Health and Development Iodine Deficiency Study Group Report. Am J Clin Nutr 79: 231-237.

11. Hollingsworth DR. Hyperthyroidism in pregnancy. In: Ingban SH, Braverman LE, eds. 5th Ed. Werner's The Thyroid. A Fundamental and Clinical Text. Philadelphia, JB Lippincott; 1986: 1043-1063.

12. Nazarpour S, Ramezani Tehrani F, Simbar M, Tohidi M, Alavi Majd H, Azizi F (2017) Effects of levothyroxine treatment on pregnancy outcomes in pregnant women with autoimmune thyroid disease. Eur J Endocrinol. 176 (2): 253-265.

13. Nazarpour S, Ramezani Tehrani F, Simbar M, Tohidi M, Minooee S, Rahmati M, Azizi F (2017) Effects of levothyroxine on pregnant women with subclinical hypothyroidism, negative for thyroid peroxidase antibodies. J Clin Endocrinol Metab. 103 (3): 926-935.

14. Maraka S, Mwangi R, Yao X, Sangaralingham LR, Singh Ospina NM, O'Keeffe DT, Rodriguez Gutierrez R, Stan M, Brito JP, Montori VM, McCoy RG (2019) Variation in treatment practices for subclinical hypothyroidism in pregnancy: US national assessment. J Clin Endocrinol Metab. Sep; 104 (9): 3893-3901. Epub Apr 24. PMID: 31127823.

15. Korevaar T.I. (2019) Initiation of Levothyroxine Therapy for Subclinical Hypothyroidism during Pregnancy in the United States. Clin Thyroidol 31: 318-321.

Copyright: (C2021 Boyana Trifonova, This is an open-access article distributed under the terms of the Creative Commons Attribution License, which permits unrestricted use, distribution, and reproduction in any medium, provided the original author and source are credited. 